\title{
PEMANTAPAN LITERASI MULTIMEDIA GURU-GURU SMPK SANG TIMUR DALAM PERANCANGAN MEDIA AJAR DIGITAL
}

\author{
Daniel Ginting ${ }^{1}$, Vincentius Valiandy Jiuangga ${ }^{2}$ \\ ${ }^{1,2}$ Universitas Ma Chung \\ e-mail: daniel.ginting@machung.ac.id, vincentius.valiandy@machung.ac.id
}

\begin{abstract}
Abstrak
Pengabdian kepada masyarakat ini dilaksanakan di SMP Katolik Sang Timur, Malang. Terdapat sembilan guru SMPK Sang Timur saat ini menghadapi kendala dalam mengelola kelas pengajaran jarak jauh. Kegiatan pengabdian masyarakat ini diawali dengan observasi kegiatan remote teaching dan dilanjutkan dengan workshop. Tulisan ini bertujuan untuk memberikan gambaran tentang pengalaman guru SMPK Sang Timur dalam mengelola kelas jarak jauh dan hasil pelatihan yang telah mereka ikuti untuk meningkatkan kemampuan mendesain media digital. Hasil pre-test dan post-test melalui analisis paired sample t-test menunjukkan bahwa terdapat perbedaan yang signifikan antara rerata pre-test dan post-test. Rata-rata post-test $(76,44)$ jauh lebih tinggi daripada pre-test $(36,33)$. Disimpulkan bahwa kegiatan pengabdian kepada masyarakat melalui workshop ini berdampak positif dalam memantapkan pengetahuan guru SMPK Sang Timur dalam hal penyiapan media digital untuk pembelajaran jarak jauh. Dari hasil penilaian terhadap video-video yang dibuat oleh guru disimpulkan bahwa kualitas media ajar tersebut sudah mencapai kategori baik.
\end{abstract}

Kata kunci: Multimedia, digital, media, pengajaran jarak jauh, pandemi, COVID-19

\begin{abstract}
This community service was held at Sang Timur Catholic Junior High School, Malang. Nine teachers from SMPK Sang Timur are currently facing obstacles in managing remote teaching classes. This community service activity begins with the observations of remote teaching activities and continued with workshops. This paper aims to provide a sketch of SMPK Sang Timur teachers 'experience in managing remote classes and the results of the training they have participated to improve their ability to design digital media. The results of the pre-test and post-test through the analysis of the paired sample t-test indicate that there is a significant difference between the mean of the pretest and that of the post-test. The mean of the post-test (76.44) is much higher than that of the pre-test (36.33). It is concluded that the community service activities through this workshop have a positive impact on consolidating the knowledge of SMPK Sang Timur teachers in terms of preparing digital media for remote teaching. From the results of the assessment of the videos made by the teacher, it was concluded that the quality of the teaching media had reached a good category.
\end{abstract}

Keywords: Multimedia, digital, media, remote teaching, pandemic, COVID-19 


\section{PENDAHULUAN}

Tidak ada satu pun dari kita pernah menduga bahwa di awal tahun 2020 model pengajaran di seluruh satuan pendidikan harus dipindahkan ke kelas daring secara masif dan drastis. Masih terekam jelas dalam ingatan kami akan berbagai ragam reaksi dari para pendidik di awal tahun 2020 itu. Tidak sedikit para guru dari berbagai jenjang satuan pendidikan merasa khawatir akan kemampuan mereka sendiri bila mereka mampu merancang kelas daring untuk siswasiswa mereka (Heckart et al., 2020; Hu et al., 2021). Saat penulis menjalankan survey lapangan dengan melakukan wawancara, guru-guru mengaku ada banyak kendala teknis dan non teknis saat kelas daring ini dijalankan: koneksi internet, dukungan perangkat teknologi lain, latar belakang pengetahuan teknologi, manajemen waktu, kuota internet, masalah jaringan dan seterusnya. Di beberapa tempat terpencil di belahan bumi Indonesia lain di mana jaringan internet menjadi sangat sulit, guru hampir kehilangan akal untuk menemukan jalan bagaimana kelas jarak jauh ini bisa dilaksanakan. Keadaan darurat masa pandemik ternyata juga menjadi momen krusial bagi para pendidik untuk menemukan solusi terhadap keterbatasan-keterbatasan mereka.

Salah satu faktor yang menentukan keberhasilan belajar siswa di kelas yang sangat mengandalkan multimedia sebagai media pengajaran adalah desain media yang disiapkan guru. Dalam perspektif teori beban kognitif pembelajaran multimedia, media yang baik adalah media yang mampu merangsang otak untuk mengintegrasikan informasi baru dengan pengetahuan awal yang telah dimiliki siswa (Kalyuga, Chandler, \& Sweller, 1998) tanpa harus membuatnya bekerja terlalu keras. Cognitive overload adalah suatu kondisi di mana memori kerja tidak lagi mampu memproses informasi di otak karena tuntutan pemrosesan tugas belajar lebih besar daripada kapasitas pemrosesan sistem pemrosesan informasi manusia (Sweller, 1994; Sweller, 1999; Sweller, 2005). Pembelajaran merupakan rekonstruksi pengetahuan yang erat kaitannya dengan proses akuisisi skema (Chi, Glaser, \& Rees, 1982). Akuisisi skema adalah proses di mana orang merekonstruksi pengetahuan mereka sebagai jaringan fakta dan konsep yang terhubung dan kemudian mereka menggunakan bangunan pengetahuan ini untuk memahami informasi baru (Anderson \& Bower, 1983). Ketika seseorang menjadi sangat mahir dalam bidang pekerjaan atau domain tertentu, mereka akan secara otomatis mengaktifkan skema tersebut selama pemecahan masalah (Sweller \& Chandler, 1995). Karena mereka memiliki skema yang terstruktur dengan baik, mereka mampu dan mampu menyelesaikan masalah dengan cepat dengan mengelompokkan masalah sesuai dengan struktur karakteristiknya (Egan \& Schwartz, 1979). Dari penjelasan tersebut dapat disimpulkan bahwa belajar adalah suatu kegiatan yang berkaitan dengan upaya menyimpan skema otomatis dalam memori jangka panjang dan bertujuan untuk memfasilitasi memori kerja untuk menyelesaikan masalah dengan sedikit atau tanpa usaha berfikir keras 
(effortless). Sebaliknya, ketika siswa belum memiliki struktur skema yang sempurna, mereka membutuhkan lebih banyak latihan, dan proses belajar mereka umumnya relatif lambat.

Pengabdian masyarakat ini dilangsungkan di Sekolah Menengah Pertama Katolik Sang Timur, Malang. Salah satu kelemahan input pendidikan yang perlu disiasati saat ini adalah keterampilan guru dalam hal mengelola kelas daring. Kebutuhan ini menjadi sangat mendesak mengingat keadaan eksternal pandemik memaksa semua pihak termasuk SMPK Sang Timur beralih kelas daring secara penuh. Pihak sekolah mengaku bahwa pengalaman mengajar daring dan penguasaan terhadap aplikasi digital masih dirasa kurang. Guru telah terbiasa dengan format tatap muka. Sementara di pihak lain, tuntutan keadaan saat ini mau tidak mau membuat mereka harus segera beradaptasi dengan belajar mengelola kelas jarak jauh. Dari hasil interview dengan sembilan guru, mereka mengaku telah menjalankan kelas daring. Namun demikian, mereka mengaku bahwa pengetahuan dan keterampilan mereka untuk menggunakan aplikasi digital untuk membuat video ajar terbatas. Selama ini mereka belajar menyiapkan materi ajar itu sendiri dengan menonton video tutorial di Youtube dan berdiskusi dengan rekan sejawat.

Menyiapkan media yang baik adalah keharusan untuk menjamin proses belajar mengajar yang efektif. Sementara, dari pengamatan kami di lapangan, pengetahuan multimedia para guru ini sangat kurang, maka kegiatan pengabdian masyarakat ini dijalankan. Diharapkan melalui pelatihan, para guru memiliki bekal pengetahuan multimedia yang cukup baik sehingga mereka mampu merancang media dan mengelola kelas jarak jauh dengan baik. Tulisan ini bertujuan untuk memberikan sketsa pengalaman para guru SMPK Sang Timur dalam mengelola kelas jarak jauh dan hasil dari pelatihan yang mereka ikuti dalam rangka meningkatkan kemampuan merancang media digital.

\section{METODE}

Kegiatan abdimas ini diawali dengan beberapa tahapan: tahapan obervasi, tahapan perencanaan, tahapan penyelesaian masalah dan tahapan evaluasi. Pada tahap obervasi, penulis melakukan pengamatan kegiatan mengajar daring dari guruguru SMPK Sang Timur. Selama pandemik, pengamatan dilakukan dengan cara melibatkan diri sebagai pengamat dalam beberapa kegiatan tatap maya dengan para guru di kelas daring. Di kesempatan lain, penulis juga melakukan wawancara untuk menggali informasi lebih jauh tentang pengalaman mereka tentang kelas jarak jauh.

Setelah melewati tahap perencanaan, penulis menjalani tahap perencanaan. Pada tahap perencanaan, penulis menjalankan analisis situasi setelah mendapatkan gambaran cukup tentang praktik kelas jarak jauh dari para guru SMPK Sang Timur, dan menyusun strategi untuk menguatkan pengetahuan multimedia mereka.

Tahap penyelesaian masalah dilakukan dengan cara memberikan kegiatan pendampingan secara daring. 
Pada tanggal 7-8 Juli dilakukan workshop yang diikuti oleh sekitar 10 orang guru. Pada hari pertama workshop adalah tentang "Kiat-Kiat Merancang Desain Pembelajaran Berbasis Multimedia." Sementara hari kedua adalah tentang "Menyiapkan Desain Multimedia dalam bentuk Video." Tujuan dari workshop adalah setelah mengikuti workshop ini, Bapak Ibu guru mampu menjelaskan prinsipprinsip pengajaran berbasis multimedia dan merancang satu media yang dapat digunakan untuk mengajar di kelas jarak jauh. Adapun contoh-contoh pertanyaan dalam tes itu dirangkum sebagai berikut:

Tabel 1. Dimensi dan Indikator Tes

\begin{tabular}{lll}
\hline No & Dimensi & \multicolumn{1}{c}{ Indikator } \\
\hline 1 & Prinsip koherensi & $\begin{array}{l}\text { Menjelaskan topik pembelajaran dengan power point } \\
\text { yang berisi teks dan gambar } \\
\text { Suara latar yang merdu dan latar power point yang } \\
\text { beranimasi pada video yang disiapkan guru adalah } \\
\text { unsur-unsur yang membuat siswa sulit memahami materi } \\
\text { yang diajarkan } \\
\text { Guru menggunakan text cues, picture-based cues dan } \\
\text { sound-based cues } \\
\text { Guru mendekatakan gambar dan teks yang menjelaskan } \\
\text { bagian-bagian dari gambar }\end{array}$ \\
3 & Prinsip redundansi & Prinsip persinyalan \\
4 & $\begin{array}{l}\text { a. Prinsip kedekatan } \\
\text { spasial }\end{array}$ & $\begin{array}{l}\text { Guru mampu menjelaskan dengan tampilan teks/gambar } \\
\text { secara simultan }\end{array}$ \\
5 & $\begin{array}{l}\text { Prinsip personalisasi } \\
\text { Prinsip umpan balik }\end{array}$ & $\begin{array}{l}\text { Guru menggunakan Bahasa penyampaian sederhana } \\
\text { Guru memberikan upan balik elaborative sesegera } \\
\text { mungkin }\end{array}$ \\
7 & Prinsip & $\begin{array}{l}\text { Untuk mengoptimalkan proses belajar mengajar, selain } \\
\text { menunjukkan media teks/gambar, guru perlu } \\
\text { menjelaskannya } \\
\text { Untuk mengoptimalkan proses belajar mengajar, selain } \\
\text { menunjukkan menjelaskan, guru perlu menampilkan } \\
\text { media berbentuk teks/gambar }\end{array}$ \\
\hline
\end{tabular}

Tahap selanjutnya adalah tahap evaluasi. Tahap evaluasi dilakukan dengan cara melangsungkan pre-test dan post-test. Tes yang dirancang oleh penulis sendiri ini terdiri dari lima belas pertanyaan pilihan ganda: di mana masing-masing pertanyaan memiliki empat atau lima pilihan. Tes ini dijalankan dengan aplikasi Socrative.
Untuk menjamin kejujuran dari tes ini, semua peserta diwajibkan menghidupkan kamera dan dilarang untuk membuka web browser apa pun untuk mendapatkan jawaban. Untuk analisis data, penulis menggunakan uji statistika paired sample t-test untuk menguji perbedaan rerata dari hasil pre-test dan rerata dari hasil post-test. 
Selain tes, penulis melakukan penilaian hasil karya kesembilan guru tersebut dengan menggunakan rubrik penilaian video. Penulis mengembangkan sendiri rubrik penilaian yang bersifat analitik tersebut meliputi: kejelasan, keruntutan, interaksi, kualitas gambar, dan kualitas suara.

\section{HASIL DAN PEMBAHASAN \\ Gambaran Umum Lokasi}

SMPK Sang Timur berlamatkan di Jalan Bandung No.2 Kelurahan Penanggungan, Kecamatan Klojen, Malang. Sekolah ini menempati lahan seluas $1.040 \mathrm{~m} 2$. Sekolah ini terletak dalam posisi yang strategis yaitu di pinggir jalan raya Jalan Bandung. Rasio guru dan siswa berkisar 1: 15. Kondisi ini memang cukup ideal dalam penyelenggaraan pendidikan.

Terdapat sembilan guru yang terlibat dalam kegiatan abdimas ini. Mereka mengajar mata pelajaran yang berbeda mulai dari ilmu sains sampai ilmu bahasa asing (Inggris). Mereka semua memiliki gelar sarjana strata 1 . Selama ini, mereka melakukan pengembangan diri untuk TIK secara mandiri dengan aktif menonton video tutorial di Youtube dan mengikuti diskusi bersama MGMP.

\section{Pelaksanaan Kegiatan Pengabdian}

Pada bagian pelaksanaan abdimas masa pandemik ini, penulis mewawancarai para guru. Dari hasil wawancara tersebut ditemukan bahwa kelas jarak jauh yang mereka jalankan telah memberikan manfaat-manfaat yang positif. Mereka mengaku bahwa guru semakin adaptif dengan teknologi: penggunaan peralatan teknologi semakin tinggi. Kelas jarak jauh telah melatih anak-anak untuk semakin bertanggungjawab dan belajar mandiri. Kelas jarak jauh semakin memperlihatkan sisi keprbadian anak didik dari sisi kemandirian dan tanggung jawab). Guru bisa mengatur pembelajaran lebih fleksibel

Namun demikian, beberapa kendala selama menjalankan kelas jarak jauh pada semester genap tahun ajaran 2020-2021 juga dilaporkan. Misalnya, pertama, beberapa siswa tidak bisa tepat waktu dalam mengumpulkan tugas. Guru melaporkan bahwa beberapa siswa tidak mengerjakan tugas-tugas yang diberikan guru sampai semester berakhir. Akhirya, guru berinisitatif mengunjungi rumah anak di samping memberitahu masalah ini kepada orang tua melalui Whatsapp. Juga dilaporkan bahwa beberapa siswa tidak bisa mengikuti pertemuan telekonferensi sesuai jadwal. Hal ini disebabkan karena beberapa siswa mengaku bahwa mereka tidak memiliki peralatan teknologi penunjang (handphone atau laptop) untuk bisa mengikuti pertemuan telekonferensi. Selain itu, koneksi internet yang lemah dilaporkan juga menjadi kendala lainnya. Kedua, guru menduga bahwa keterlambatan dalam masalah tugas juga disebabkan karena tingkat kedisiplinan anak dalam mengatur waktu belajar dan mengerjakan tugas rendah. Ini terjadi pada kelompok anak-anak tertentu yang pada dasarnya tidak memiliki masalah dengan peralatan penunjang untuk kelas daring. Ketiga, guru mengaku bahwa media ajar yang mereka siapkan selama semester lalu kurang menarik atau tidak mendorong 
anak-anak untuk belajar. Mereka merasa bahwa masalah ini disebabkan karena rendahnya kemampuan mereka di dalam merancang desain multimedia yang relevan untuk kelas jarak jauh.

Berdasarkan dari hambatan ini, penulis mengambil inisiatif untuk melakukan pertemuan dengan para guru guna menemukan solusi untuk kendala yang mereka hadapi. Karena interaksi secara langsung selama masa pandemic sulit dilakukan, penulis dan para guru bersepakat untuk melakukan pertemuan secara daring. Dalam pertemuan itu disepakati beberapa keputusan-keputusan.

Pertama, perlu dilakukan survey untuk memetakan kesulitan-kesulitan yang dihadapi siswa: ketersediaan sarana pendukung untuk kelas jarak jauh (handphone, internet, atau laptop); kemandirian; dan dukungan orang tua. Pemetaan kendala ini sangat penting untuk menemukan solusi bagi setiap kelompok masalah di atas sehingga keterlambatan pengumpulan tugas atau kerajinan untuk mengikuti jadwal kelas dapat ditingkatkan. Misalnya, bagi siswa yang mengalami kesulitan jaringan internet atau sarana pendukung, diputuskan bahwa guru menyiapkan video tentang topik-topik yang diajarkan. Video itu diunggah di Youtube sehingga sewaktu-waktu para siswa bisa mengakses materi itu dan belajar secara mandiri. Agar video itu efektif yang memiliki daya pendorong buat anak untuk belajar, guru memberikan rincian instruksi tugas di video tersebut. Dengan cara itu, maka anak mau tidak mau akan menonton video itu sampai tuntas. Penulis menyarankan guru untuk mengistalasi Youtube Studio untuk memantau keaktifan siswa melalui video yang dibagikan itu.

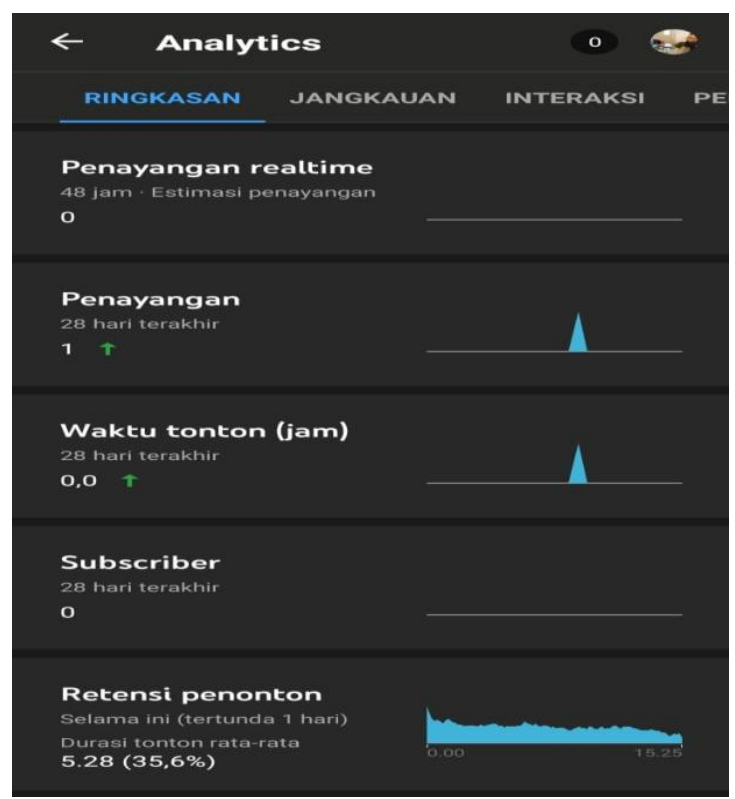

Gambar 1. Youtube Studio guru untuk memantau siswa dalam belajar

Kedua, bagi siswa yang bermasalah dengan kedisiplinan, para guru bersepakat untuk melakukan kordinasi yang intensif dengan para orang tua melalui grup Whatsapp. Dalam kordinasi dengan orang tua itu, guru menyiapkan Rencana Pembelajaran Kelas (RPK) untuk satu semester yang berisi tujuan pembelajaran, tugas-tugas yang harus diselesaikan beserta tanggal/tenggat waktunya. Dengan membaca RPK ini, orang tua membantu memonitor perkembangan belajar dan mengingatkan anak akan hal-hal yang harus mereka tuntaskan. Komite sekolah juga dilibatkan dalam program ini agar komunikasi antar para wali dan sekolah dapat berjalan lancar. 
Ketiga, terkait dengan permasalahan keterampilan merancang desain multimedia yang baik, maka diputuskan untuk diadakan workshop. Kegiatan workshop secara daring ini diikuti dengan antusias oleh semua guru. Penulis selaku narasumber memberi penjelasan point-demi point mengenai prinsip multimedia kepada mereka. Sesi ini dimulai dari jam 09.0012.00 dan diwarnai dengan interaksi antara narasumber dan para guru. Beberapa aplikasi yang digunakan untuk meningkatkan interaksi itu adalah seperti Pear Deck, Socrative, No Hand on app, Mentimeter dan Go Formative.

\section{Kegiatan Workshops}

Selama workshop, penulis mengamati bahwa banyak guru yang belum menyadari bahwa music latar dan latar virtual yang beranimasi yang mereka gunakan dalam membuat video adalah elemen-elemen itu untuk membuat siswa tertarik dengan materi ajar. Namun demikian, dalam perspektif teori beban kognitif sesungguhnya elemen-elemen music latar dan animasi adalah ektrinsik yang mengganggu dan memecah perhatian siswa (Sweller, 1999; Sweller, 2005; Sweller \& Chandler, 1995). Akibatnya, besar kemungkinan siswa akan mengalami kejenuhan kognitif di mana otak sulit memproses informasi penting yang menjadi subtansi pengajaran.

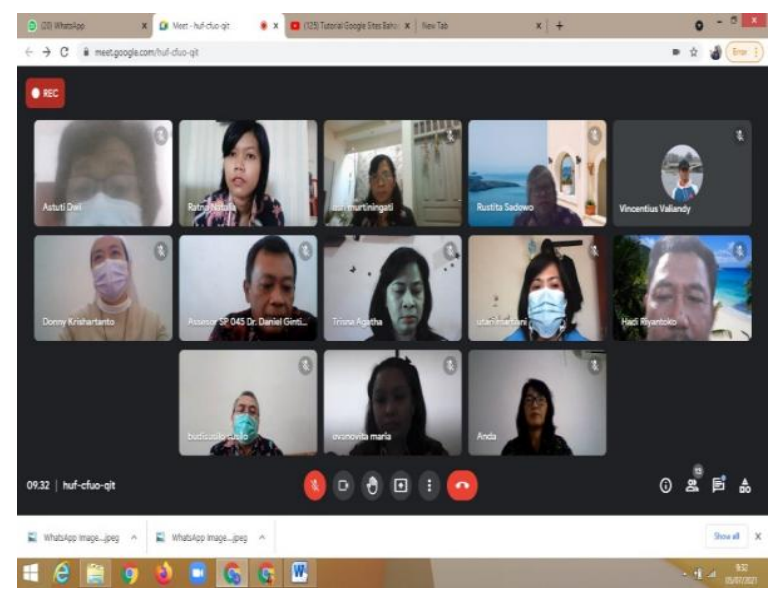

Gambar 2. Suasana workshop daring

Hal kesalahpahaman lain adalah guru mengaku sering terlambat memberi umpan balik (feedback) kepada siswa. Mereka mengaku penundaan untuk memberi feedback terjadi karena kesibukan. Penulis menjelaskan bahwa penundaan itu justru berpotensi mengurangi kualitas belajar anak. Idealnya, pemberian umpan balik harus dibuat sesegera mungkin untuk menghindari temporal discontinguity (Sweller, 1994): kesenjangan waktu atau jeda waktu terlalu panjang untuk kebutuhan mendapatkan penjelasan atas jawaban yang siswa berikan. Semakin cepat, maka kapasitas memori anak dapat digunakan secara optimal untuk memperbaiki jawaban melalui feedback guru tersebut.

Kemampuan guru dalam memahami kedekatan spasial cukup baik (spatial contingutiy). Misalnya, mereka dapat memilih metode: meletakkan teks di dekat gambar yang dijelaskan. Saat sesi tanya jawab pada 
workshop (perhatikan Gambar 3), mereka dapat menjelaskan bahwa gambar A jauh lebih baik dari pada gambar B. Menurut mereka, gambar A memudahkan siswa paham tentang anatomi otak tanpa harus repot-repot memindai teks dan gambar seperti gambar B. Sejalan dengan itu, teori beban kognitif mengafirmasi argument dari guru. Spatial discontiguity memang menguras kapasitas memori kerja tidak terkuras. (Sweller \& Chandler, 1995). Perhatian siswa akan terpecah untuk melihat teks di bagian bawah yang jauh dari gambar dan menghubungkan teks tersebut dengan gambar kembali. Demikian sebaliknya.

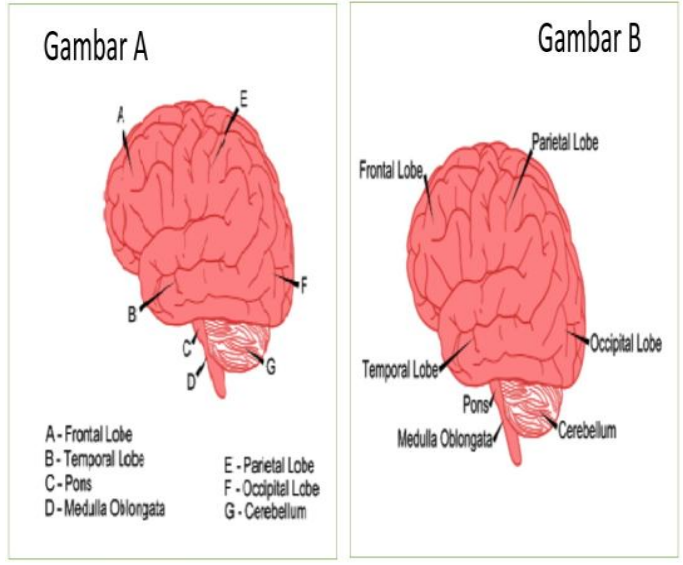

Gambar 3. Kedekatan Spasial tentang anatomi otak

Kesalahpahaman lain juga terjadi saat guru diuji kemampuan mereka tentang memilih metode yang terbaik untuk menjelaskan kejadian petir (lihat Gambar 4). Kebanyakan guru memilih metode $B$ yaitu selain memberikan penjelasan naratif, guru juga menampilkan gambar dan teks yang panjang. Meskipun seolah metode B ini sepintas sangat detail, metode ini sesungguhnya tidak efektif. Teks panjang pada slide dan penjelasan guru pada dasarnya relative sama, belum lagi ada gambar tentang kejadian petir. Kesamaan informasi antara teks dan penjelasan guru itu menjadi redundant atau mubazir. Siswa mendengarkan penjelasan guru (audio) dan pada waktu yang sama membaca teks. Akibatnya, siswa menguras kapasitas memori kerja mereka karena membagi perhatian pada dua hal yang sama. Idealnya, teks yang panjang itu dihilangkan, dan pemberian materi cukup dilakukan dengan menjelaskan secara naratif dengan suara guru disertai gambar.

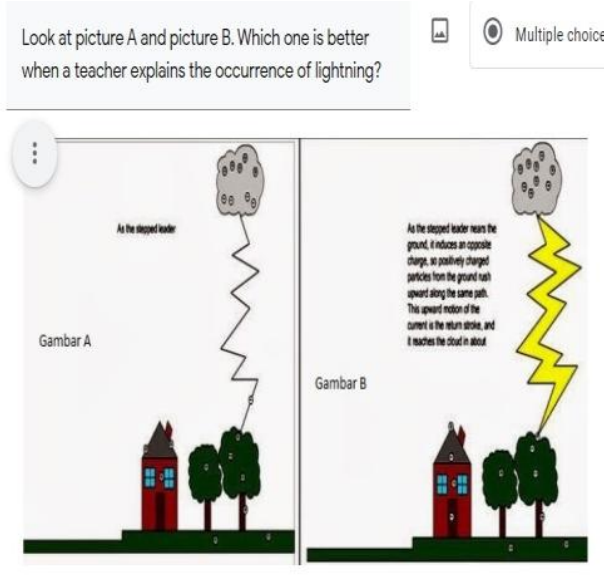

Gambar 4. Prinsip redundansi saat menjelaskan kejadian petir

Pelatihan tentang menyiapkan media ajar berupa video juga diberikan kepada guru SMPK Sang Timur. Dalam pemaparan ini, pembicara menegaskan ciri-ciri dari video yang baik seperti kesesuaian isi video dengan tujuan pembelajaran dan menyesuaikan dengan pengalaman belajar siswa. Selain itu perlu dipertimbangkan tiga hal dalam menyiapkan video yaitu beban kognitif, interaksi (engagement) 
Jurnal Widya Laksana, Vol.11, No. 1, Januari 2022

dan belajar aktif (active learning). Ada tiga aplikasi yang diajarkan dalam workshop ini yaitu: Youtube, Tik Tok dan In Shot.

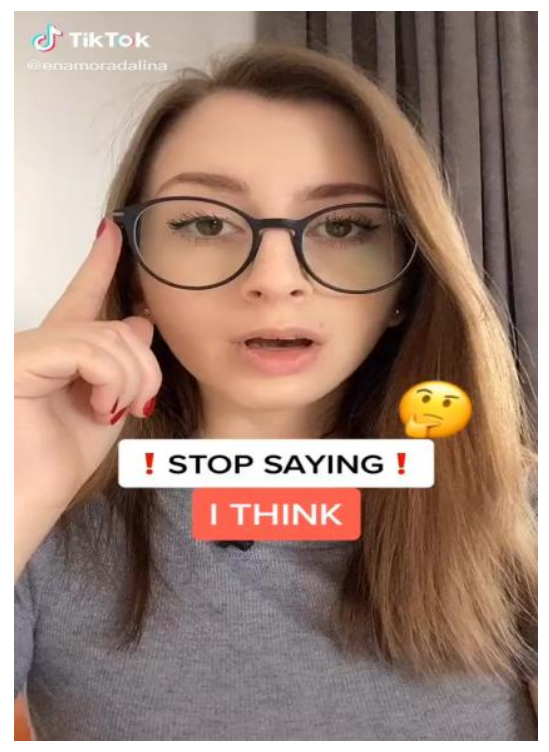

Gambar 5. Contoh media TikTok untuk pembelajaran

\section{Kemampuan Menghasilkan Media Digital}

Ada beberapa pertimbangan mengapa Youtube digunakan sebagai media pembelajaran. Pertama, kanal Youtube ini mudah digunakan bagi guru untuk mengelolanya dan selanjutnya membagikan content pengajarannya. Mengunggah video, menyetting mode publikasi (listed, privacy atau public), dan membagikan link (shareable) adalah hal-hal yang mudah dilakukan oleh guru. Bagi siswa, mereka dapat menontonnya kapan dan di mana saja. Mereka dapat mereview dan menambah pengetahuan mereka dengan menonton video itu. Menyediakan materi pembelajaran di Youtube relative sangat memihak kepentingan anak yang mengalami kesulitan untuk mengikuti kelas sinkronik. Tik Tok adalah media lain yang diajarkan. Pada kenyataannya, aplikasi ini sangat popular di kalangan remaja. Meskipun durasi Tik Tok sangat singkat, guru dapat menyisipkan pesan ajarnya melalui aplikasi ini. Berikut ini adalah hasil karya video yang diunggah oleh para guru SMPK Sang Timur.

Karya guru seni music https://www.youtube.com/watch?v=HH 1coc63Das

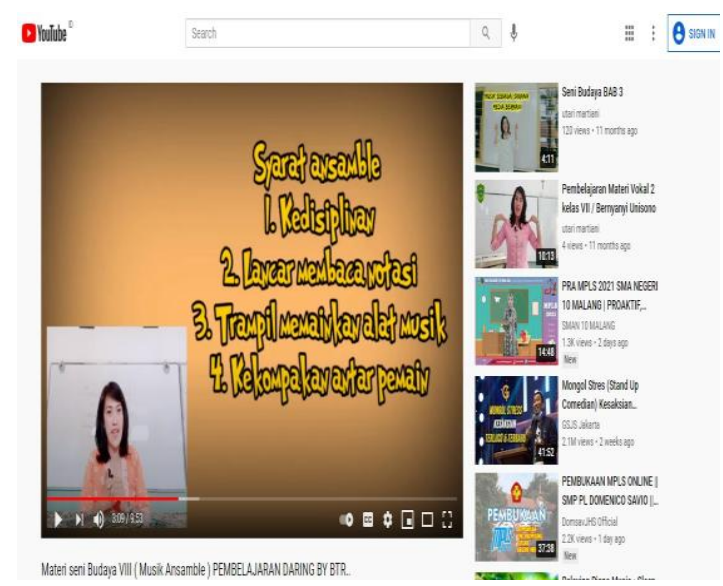

Karya guru Matematika https://www.youtube.com/watch?v=eKA wfs4B9m4

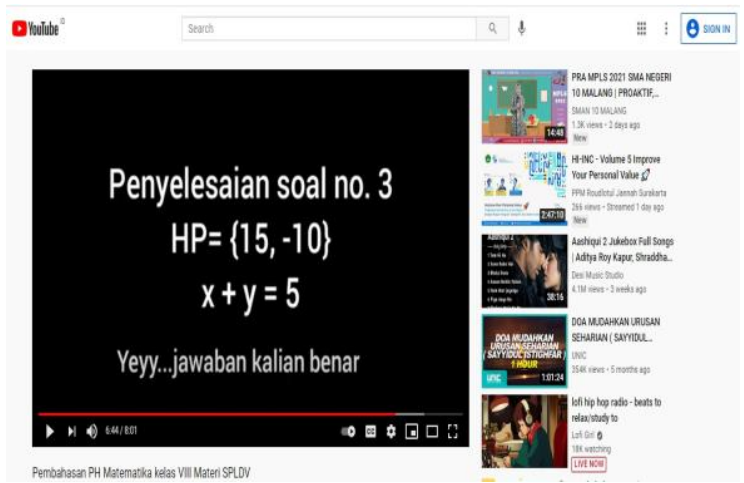


Karya guru Bahasa Inggris https://www.youtube.com/watch?v=Qh R7Nu4HFsw\&t=8s

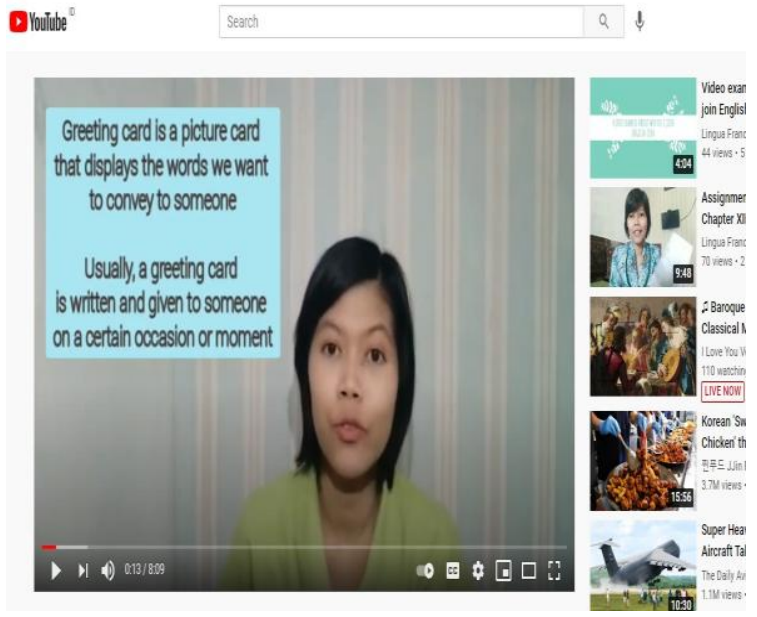

Tiga karya video yang disiapkan oleh guru seni musik, guru matematika, dan guru Bahasa Inggris dapat dikategorikan sangat baik oleh karena video-video tersebut telah memenuhi kaidah-kaidah teoritis perancangan multimedia. Ketiga video tersebut berisi esensi dari topik yang diajarkan. Unsur-unsur ekstrinsik seperti music latar telah berhasil disisihkan sehingga siswa fokus kepada penjelasan guru. Kalaupun ada music, mereka menempatkannya pada bagian awal pembuka atau di bagian akhir atau penutup. Ketiga guru dalam video tersebut tampil dengan bahasa yang bersahabat. Selain itu, wajah mereka terlihat dalam video itu dengan jelas. Cara penyampaian Bahasa yang bersahabat dan penampilan wajah adalah tehnik yang sangat baik untuk memperkuat kesan kehadiran mereka kepada siswa yang menontonnnya. Dengan demikian, siswa merasa seolah-olah diajar dengan guru mereka sendiri sekalipun hanya dengan video.

Video kreasi para guru tersebut penulis nilai dengan rubric yang penulis kembangkan sendiri. Rubrik penilaian yang bersifat analitik tersebut meliputi: kejelasan, keruntutan, interaksi, kualitas gambar, dan kualitas suara.

\section{Evaluasi Kegiatan Pengabdian}

Di bagian awal (pre-test) dan akhir sesi workshop ini (post test), penulis menyiapkan tes. Hasil pre-test dan post-test dari pelaksanaan workshop multimedia ditampilkan pada table 2. Selanjutnya dari dua tes ini dianalisis dengan uji beda paired sample t-test melalui perangkat lunak SPSS. Dari hasil kalkulasi itu didapatkan bahwa nilai siknifikan $p$ yaitu 0.00 yang lebih kecil dari batas penolakan hipotesis nul 0.05 . Hasil ini disimpulkan bahwa ada perbedaan rerata dari pre-test dan rerata dari posttest. Sementara itu, dari hasil perbandingan rerata, terlihat bahwa rerata post-test (76.44) jauh lebih tinggi dari rerata pre-test (36.33). Maka penulis menyimpulkan bahwa ada perubahan ke arah yang lebih baik tingkat pengetahuan para guru SMPK Sang Timur setelah mengikuti workshop multimedia. 
Tabel 2. Hasil Pre-test dan Post-test tentang Multimedia para Guru SMPK Sang Timur

\begin{tabular}{rlcc}
\hline No & Nama & Pre-test & Post-test \\
\hline 1 & Guru 1 & 40 & 73,33 \\
2 & Guru 2 & 33,33 & 66,67 \\
3 & Guru 3 & 40 & 86,67 \\
4 & Guru 4 & 40 & 86,67 \\
5 & Guru 5 & 33,33 & 73,33 \\
6 & Guru 6 & 40 & 80 \\
7 & Guru 7 & 26,67 & 46,67 \\
8 & Guru 8 & 26,67 & 86,67 \\
9 & Guru 9 & 46,67 & 86,67 \\
\hline
\end{tabular}

\section{KESIMPULAN}

1. Peralihan ke kelas jarak jauh secara penuh selama masa pandemik, bagi guru di SMPK Sang Timur, merupakan suatu peluang untuk pengembangan diri. Mereka semakin adaptif dengan teknologi dan tertantang untuk meningkatkan kemampuan untuk merancang kelas jarak jauh dengan memafaatkan platform-platform digital yang tersedia seperti Youtube, Tik Tok dan In Shot.

2. Pengetahuan tentang prinsip-prinsip multimedia adalah modal penting bagi para guru agar pencapaian pembelajaran melalui platform digital berjalan sempurna. Hal ini karena media merupakan salah satu faktor penting yang membantu anak untuk memproses informasi baru.

3. Media yang baik adalah media yang mampu mendorong anak mengoptimalkan kapasitas berfikirnya atau tanpa harus banyak mengeluarkannya untuk hal-hal yang tidak relevan dalam pembelajaran. Dalam hal ini, media dipastikan bebas dari unsur-unsur ektrinsik seperti music latar, animasi yang tidak relevan. Sementara itu, isi dari media itu dibuat relevan dengan mempertimbangkan pengalaman, pengetahuan dan kemampuan anak.

4. Media yang baik berisi informasi yang relevan dengan topik pembelajaran; disajikan dalam bentuk yang sederhana, namun merangsang otak untuk berfikir yaitu dengan memanfaatkan multimodalitas seperti informasi berbentuk visual (gambar/teks) dan penjelasan guru (audio).

5. Interaksi dalam proses belajar mengajar perlu didorong untuk memberikan peserta didik kesempatan bertanya selama proses pembelajaran. Model pengajaran kelas jarak jauh yang interaktif merangsang peserta didik untuk menjadi pembelajaran aktif sehingga mereka akan semakin cepat memahami pengetahuan baru yang diajarkan.

6. Kolaborasi dan dukungan dari orang tua sangat penting saat kelas jarak jauh. Orang tua perlu memberi dukungan kepada peserta didik. 
Dengan memonitor rencana pembeajara pembelajaran kelas dan aktif memonitor dan terlibat dalam grup sosial media (seperti Whatsapp) orang tua turut berpartisipasi agar perkembangan belajar (tugas) peserta didik tidak terabaikan.

\section{UCAPAN TERIMA KASIH}

Penulis mengucapkan terima kasih kepada Universitas Ma Chung dalam hal ini Lembaga Penelitian dan Pengabdian Masyarakat yang telah memberi dukungan financial terhadap pengabdian ini. Apresiasi yang tinggi disampaikan penulis kepada Suster Kepala SMPK Sang Timur dan para guru.

\section{DAFTAR PUSTAKA}

Anderson, J. R., \& Bower, G. (1983). Human associative memory. Washington, DC: Winston.

Egan, D. E., \& Schwartz, B. J. (1979). Chunking in recall of symbolic drawings. Memory \& Cognition, 7(1), 149-158.

Chi, M. T., Glaser, R., \& Rees, E. (1982). Expertise in problem solving. In R. Sternberg, Advances in the psychology of human intelligence. Hillsdale, NJ: Erlbaum.

Heckart, K., Seitz, Z., Reiter, J., Ingold, J., Francis, A., \& Hitchcock, C. (2020). Teaching Remotely During the Coronavirus Pandemic Social Education Staff. Journal Social Education, 84(3), 146-151.

Hu, X., Chiu, M. M., Leung, W. M. V., \& Yelland, N. (2021). Technology integration for young children during COVID-19: Towards future online teaching. British Journal of Educational Technology, 20(2), 125.

https://doi.org/10.1111/bjet.13106

Kalyuga, S., Chandler, P., \& Sweller, J. (1998). Levels of expertise and instructional design. Human Factors. 40(1), 1-17.

Sumardi, S., \& Nugrahani, D. (2021). Adaptation to emergency remote teaching: Pedagogical strategy for pre-service language teachers amid COVID-19 pandemic. Turkish Online Journal of Distance Education, 22(2), 81-93. https://doi.org/10.17718/tojde.9065 53

Sweller, J. (1994). Cognitive load theory, learning difficulty, and instructional design. Learning and Instruction, 4(1), 295-312.

Sweller, J. (1999). Instructional design in technical areas. Camberwell, Australia: ACER Press.

Sweller, J. (2005). Implications of cognitive load theory for multimedia learning. . In R. E. Mayer, The Cambridge handbook of multimedia learning. New York, NY: Cambridge University Press.

Sweller, J., \& Chandler, P. (1994). Why some material is difficult to learn. Cognition and Instruction, 12(3), 185-233. 